Article

\title{
Environmental Strategies for Selecting Eco-Routing in a Small City
}

\author{
Juan Francisco Coloma ${ }^{1, *}$, Marta García ${ }^{1}$, Yang Wang ${ }^{2}{ }^{-[}$and Andrés Monzón ${ }^{2}$ \\ 1 Betancourt Research Group, Universidad de Extremadura, 10003 Caceres, Spain \\ 2 Transport Research Centre, TRANSyT, Universidad Politecnica de Madrid, 28040 Madrid, Spain \\ * Correspondence: jfcoloma@unex.es; Tel.: +34-927251647
}

Received: 27 June 2019; Accepted: 2 August 2019; Published: 4 August 2019

check for updates

\begin{abstract}
This research aims to find the most ecological itineraries for urban mobility in a small city (eco-routes), where distances are rather short, but car dependence is really high. A real life citywide survey was carried out in the city of Caceres (Spain) with almost 100,000 inhabitants. Research was done on alternating routes, traffic, times of day, and weather conditions. The output of the study was to assess fuel consumption, $\mathrm{CO}_{2}$, and regulated pollutant emissions for different type of vehicles, routes, and drivers. The results show that in the case studied, urban roads had fewer emissions $\left(\mathrm{CO}_{2}\right.$ and pollutants) but there was an increase in the population affected by pollutants. On the contrary, bypasses reduced travel time and congestion but increased fuel consumption and emissions. Traffic conditions had a greater influence on fuel consumption in petrol vehicles than diesel ones. Therefore, there must be a balanced distribution of traffic in order to minimize congestion, and at the same time to reduce emissions and the number of people affected by harmful pollution levels. There should be a combination of regulatory measures in traffic policies in order to achieve that balance by controlling access to city centres, limiting parking spaces, pedestrianization, and lowering traffic speeds in sensitive areas.
\end{abstract}

Keywords: eco-routing; fuel consumption; emissions; climate change; road type; driving behaviour

\section{Introduction}

Recent studies concluded that over $60 \%$ of European citizens live in urban areas. They share the same space and means of transport to move around. However, they also share the harmful effects of their mobility patterns and account for $40 \%$ of total $\mathrm{CO}_{2}$ emissions from road transport and up to $70 \%$ of atmospheric pollutants [1].

Public authorities may try to reduce $\mathrm{CO}_{2}$ emissions by banning the use of private vehicles. However, certain individual driving techniques have proven to be effective [2-4].

Driving style greatly influences how much fuel a car consumes. The aim of "efficient driving" is to achieve low fuel consumption while reducing environmental pollution [5]. This simple concept includes a series of techniques, which depend on the level of the decision under consideration [6].

- Strategic decisions: Includes vehicle selection and maintenance (tyres, engine, brakes, etc.) [7].

- Operational decisions (eco-driving): Reduces fuel consumption by making gear changes at low revolutions, maintaining a constant speed, reducing accelerations and braking, and anticipating traffic by reducing the number of stops [8].

- Tactical decisions (eco-routing): Consists of choosing the itinerary with the least environmental impact. Different road types with different sections and slopes may produce different values of emissions and pollutants [9]. 
This research revolves around an analysis of tactical driving decisions, i.e., eco-routing. Ericsson et al. [10] achieved an $8.2 \%$ decrease in emissions by selecting eco-routes. Other authors [11-14] estimated that using eco-routes can reduce emissions by around $10 \%$, although they may not save time.

Bandeira et al. [15] and Mensing et al. [16] had reservations about how good efficient driving techniques are, since in some cases, the reduction in fuel consumption leads to an increase in pollutants, such as NOx, CO, and particulate matter (PM).

At present global positioning system (GPS) can find the shortest routes in distance or time, but not in terms of fuel consumption or pollutants emitted. Moreover, most of the research carried out to date has been determined through theoretical models and laboratory research in large cities with congestion problems [17-19]. Therefore, the objective of this research was to perform a test in a real-life scenario in a small city with different road types to ascertain which factors may have influenced the selection of the eco-route and in turn, to define useful environmental strategies for the authorities and road users. In particular, the influence the following factors had on several road types was studied:

- Different traffic intensity.

- Road characteristics (number of lanes, lane separation, pavement, etc.).

- Powertrain type: Diesel and petrol.

In this research, different road types were analyzed to find the most ecological itineraries for urban mobility in a small city (eco-routes), where distances are rather short but car dependence is really high. A real life citywide survey was carried out in the city of Caceres (Spain) at different times of the day and under different traffic and weather conditions.

After the introduction, Section 2 describes the methodology used to perform the eco-routing in Caceres. Section 3 describes the results and Section 4 includes a discussion comparing them with other previous studies and describes the conclusions and the policy recommendations derived from these results.

\section{Methodology}

For the purpose of this research, a real eco-routing test was carried out with different engines (diesel and petrol) and route types (urban roads and bypass) under different traffic conditions. The phases followed are described below:

1. Data on driver behavior were collected on 4 different route types in different weather and traffic conditions. Three of the itineraries selected were urban roads and one was a city bypass. All of them had different traffic intensity levels [20].

2. Driver parameters were measured using a device installed on board (OBD-key, KBM Systems Ltd., London, UK) [21]; $\mathrm{CO}_{2}$ emissions linked to these were also estimated.

3. The COPERT (Emisia, SA, Thessaloniki, Greece) [22] emissions calculator was used to estimate regulated pollutants [23]: NOx, CO, volatile organic compounds (VOC), and PM, for diesel and petrol engines.

4. The combined effects of selecting certain routes were studied for the different road and engine types as a proxy for eco-routing.

\subsection{Case Study: City of Caceres, Spain}

Caceres is a city located in the southwest of Spain, where 95,000 inhabitants live in an area of $1750 \mathrm{~km}^{2}$. It has a unique medieval old town, which was named a World Heritage site by The United Nations Educational, Scientific and Cultural Organization (UNESCO) in 1986 [24]. 
Although the old town is pedestrianized, $55 \%$ of all trips are made in privately-owned cars, $33 \%$ are made on foot and only $10 \%$ by public transport. It is a hilly city, therefore, bicycles are only used for recreation and not as a means of transport [25].

The city of Caceres excessively depends on private cars, thus new ways of persuading people to use public transport and to walk are needed. The pedestrianization of the historic center and limited-time parking areas in the center have proved to be insufficient measures for counteracting this tendency.

\subsection{Routes Selection}

Four different itineraries with different levels of traffic intensity were researched, all of which started at the University Campus (School of Technology) and finished at the train station (Figure 1).

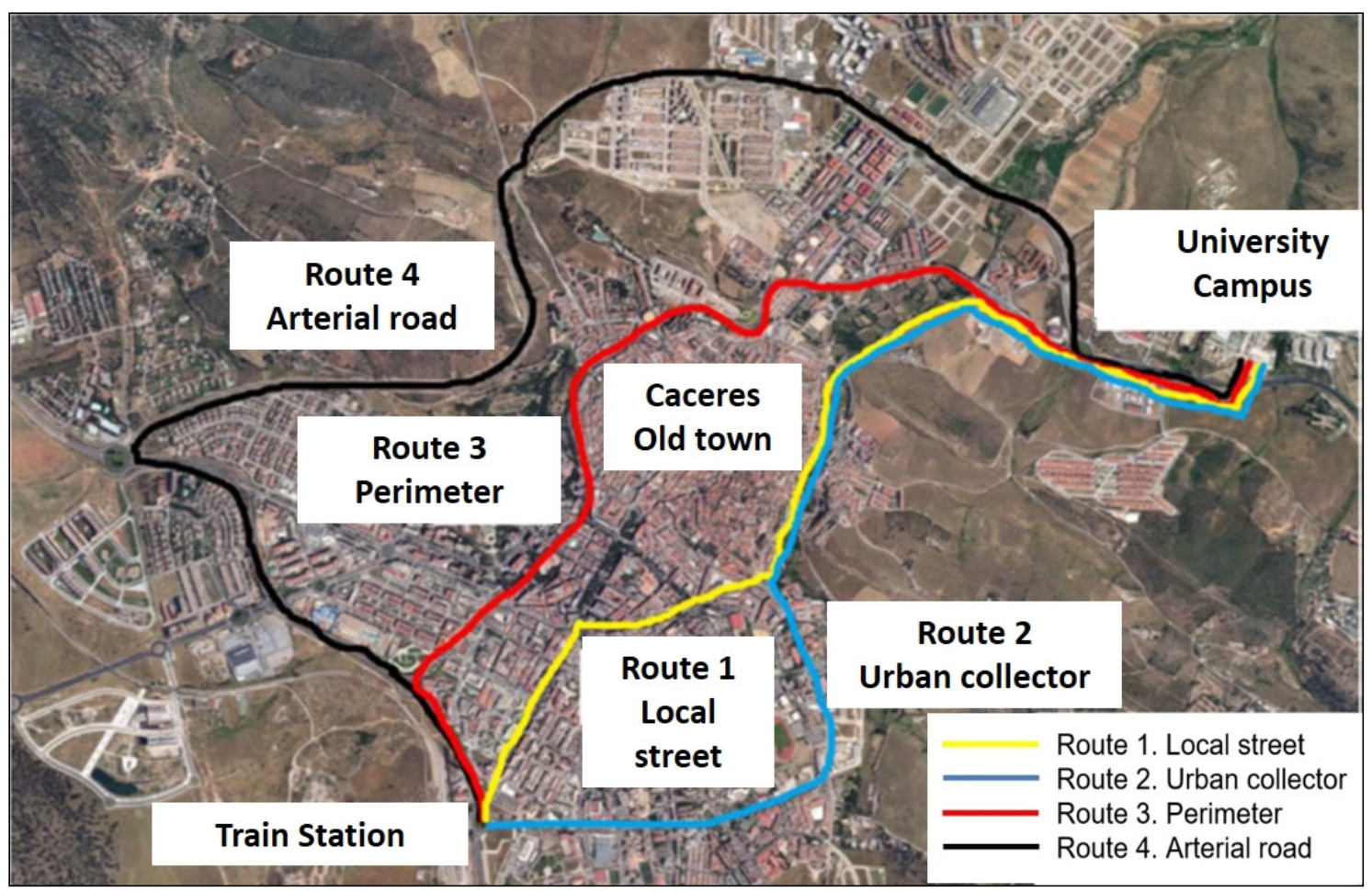

Figure 1. Different itineraries selected.

The routes selected have different characteristics but corresponded to a general classification of roads and could be applied to similar cities and traffic contexts [26]. They have been ordered by Annual Average Daily Traffic (AADT) decrease. Route 1 (local street) was an urban street that ran through the city center. Route 2 (urban collector) was the main avenue that gave access to the conference and exhibition center, hospital, and bus station. Route 3 (perimeter) was an urban road that surrounded the city. Route 4 (arterial road) was an urban motorway (level intersections with roundabouts) recently built as a city bypass. The first 3 routes were urban roads and the last one was a bypass. Table 1 shows the main characteristics of each of the selected routes.

Figure 2 represents a comparison of driving styles on each route, highlighting maximum speeds and the number of stops. 
Table 1. Route type main characteristics.

\begin{tabular}{|c|c|c|c|c|c|c|c|c|}
\hline Type & Route & Lanes & $\begin{array}{l}\text { Length } \\
(\mathbf{k m})\end{array}$ & $\begin{array}{l}\text { Travel } \\
\text { Time } \\
\text { (min) }\end{array}$ & $\begin{array}{l}\text { Average } \\
\text { Velocity } \\
(\mathbf{k m} / \mathbf{h})\end{array}$ & $\begin{array}{c}\text { Speed } \\
\text { Limit } \\
(\mathbf{k m} / \mathbf{h})\end{array}$ & $\begin{array}{c}\text { Average } \\
\text { Slope } \\
(\%)\end{array}$ & $\begin{array}{c}\text { AADT } \\
\text { (vehicles/day) } \\
{[25]}\end{array}$ \\
\hline \multirow{3}{*}{$\begin{array}{l}\text { Urban } \\
\text { Roads }\end{array}$} & $\begin{array}{l}\text { 1-Local } \\
\text { street }\end{array}$ & $1 \times 1$ lanes & 6.1 & 15 & 24.4 & 50 & 2.9 & 14960 \\
\hline & $\begin{array}{l}2 \text {-Urban } \\
\text { collector }\end{array}$ & $\begin{array}{l}2 \times 2 \text { lanes } \\
\text { separated by } \\
\text { barrier. Parking } \\
\text { both sides }\end{array}$ & 6.7 & 14 & 28.7 & $30-50$ & 2.4 & 14850 \\
\hline & 3-Perimeter & $\begin{array}{l}2 \times 2 \text { separated } \\
\text { by barrier or } \\
\text { continuous } \\
\text { double line }\end{array}$ & 6.7 & 13 & 31 & 50 & 2.2 & 12930 \\
\hline Bypass & $\begin{array}{l}4 \text {-Arterial } \\
\text { road }\end{array}$ & $\begin{array}{l}2 \times 2 \text { separated } \\
\text { by barrier. }\end{array}$ & 10.3 & 12 & 51.5 & $50-80$ & 2.0 & 10500 \\
\hline
\end{tabular}
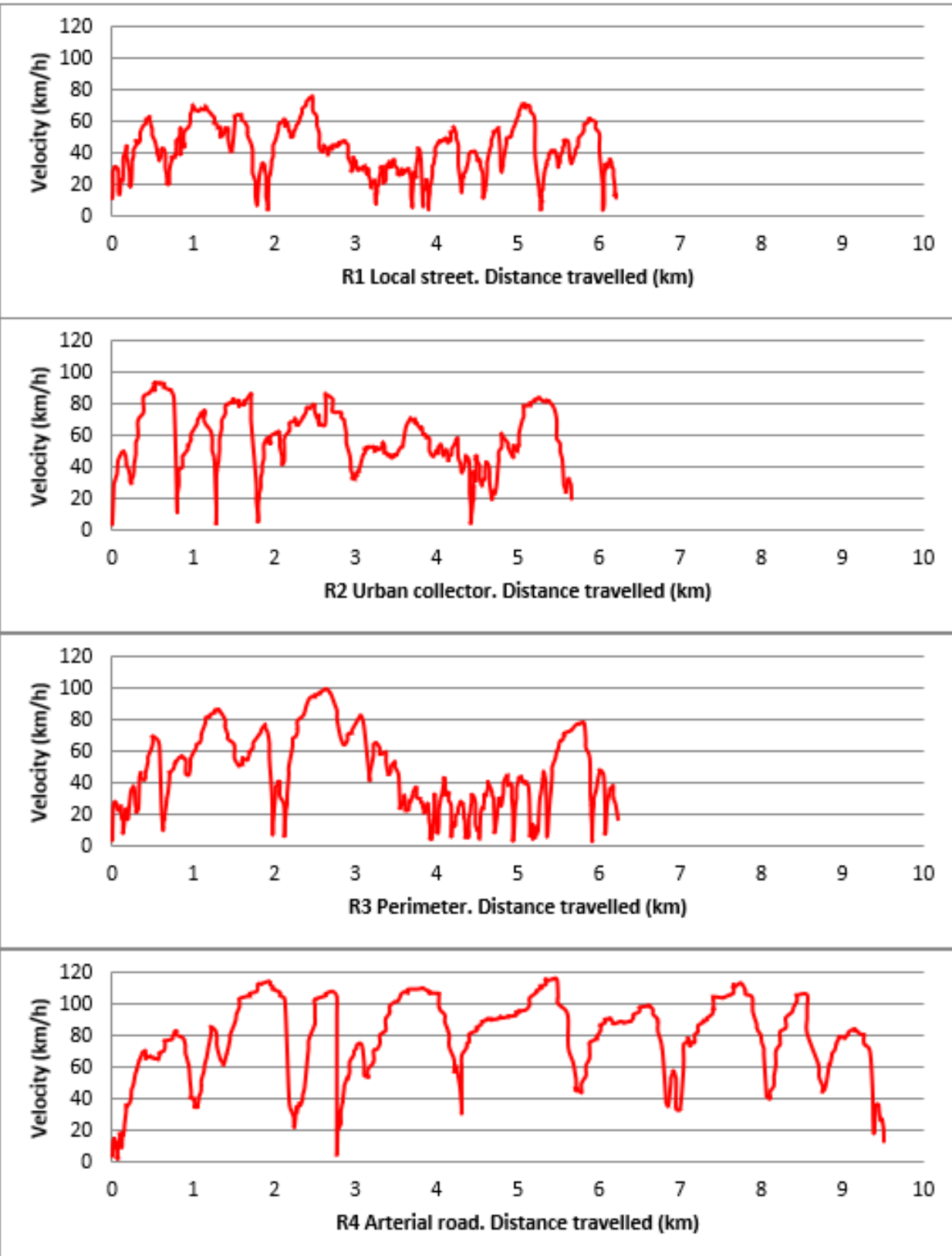

Figure 2. Instant travel speeds on the four routes. 


\subsection{Driver and Car Selection. Scheduling}

The campaign was organized with 12 drivers of different gender, age, and driving styles. The chosen sample consisted of a total of 8 men and 4 women between 21 and 44 years old, which accounts for over $51 \%$ of drivers in the Caceres census [27].

The cars used in the experiment were an Opel Astra 1.61 diesel and a Fiat 5001.21 petrol. They represented the small and medium-sized segments, respectively, and accounted for approximately $70 \%$ of the fleet in Caceres [28]. Technical information on both vehicles is shown in Table 2.

Table 2. Technical data of Diesel 1.61 and Petrol 1.21 [29].

\begin{tabular}{|c|c|c|}
\hline Items & Diesel 1.6 & Petrol 1.2 \\
\hline Commercial segment & Medium & Mini \\
\hline Transmission Gearbox & Manual & Manual \\
\hline Authorized mass (kg) & 2010 & 1305 \\
\hline Power $(\mathrm{HP})$ & 110.05 & 93.75 \\
\hline $\begin{array}{l}\text { Dimensions }(\mathrm{LxWxH}) \\
(\mathrm{mm})\end{array}$ & $4419 \times 1814 \times 1510$ & $3546 \times 1627 \times 1488$ \\
\hline Seats & 5 & 4 \\
\hline $\mathrm{CO}_{2}$ emissions $(\mathrm{g} / \mathrm{km})$ & 109 & 115 \\
\hline $\mathrm{CO}_{2}$ emissions $(\mathrm{g} / \mathrm{l})$ & 2658 & 2347 \\
\hline Consumption classification & A & D) \\
\hline
\end{tabular}

Testing was carried out from the 2 May to 7 May 2017. Three driving turns of $4 \mathrm{~h}$ were established for each car in which two different drivers took turns every hour to avoid fatigue. Drivers travelled the 4 routes continuously and randomly for $12 \mathrm{~h}$ a day in order to drive in different traffic situations (free flow, moderate, and congestion). Weather conditions also varied as one day it rained, 2 days were cloudy, and the rest were rather sunny.

Caceres mobility data [30] was used to adjust driving turns and cover peak hours. In Caceres, there are 3 peak hours related to the main movements of traffic in the city. Between 8 a.m-9 a.m: Dropping off at schools and arrivals at places of work (10\% higher than the average), 2 p.m: Lunch ( $28 \%$ above the average) and between 6 p.m- 7 p.m. returning home ( $15 \%$ above the average). In light of this, the following driving turns were selected:

1. 1st period. Morning peak hour: 7:30-11:30 am

2. 2nd period. Lunchtime: 12:00-4:00 pm

3. 3rd period. Evening peak hour: 4:30-8:30 pm

\subsection{Data Acquisition and Fuel Consumption}

The study was based on an analysis of the driving parameters for each of the sample segments, which were measured using an OBD-key device installed on board (Figure 3).
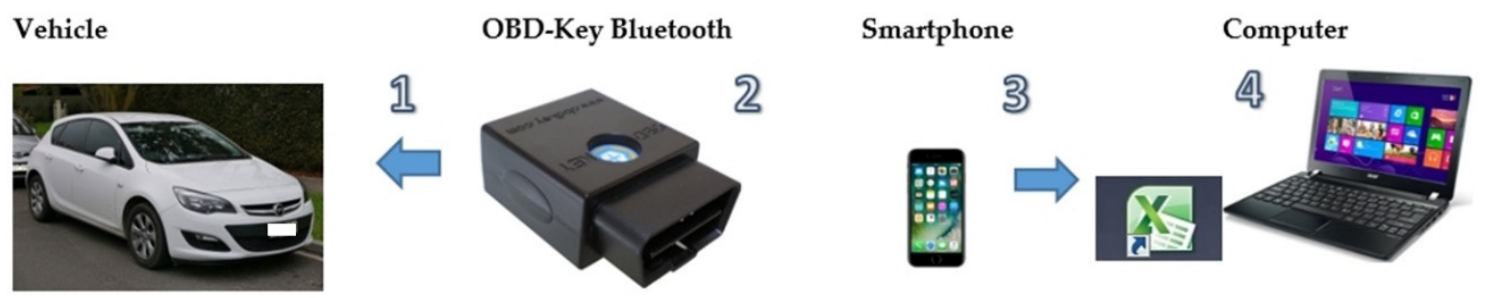

Figure 3. Data acquisition equipment.

The OBD-key [21] was a device used for measuring vehicle performance and it could monitor 128 variables by the second, including GPS position, travel time, revolutions per minute (rpm), speed, 
and fuel consumption. A mobile application was used to send this information to a smart phone, with which all the data could be managed on a standard spreadsheet.

In previous research [31,32], it was concluded that the most influential fuel consumption factors were the number of stops, rpm, and acceleration/deceleration. Therefore, these parameters were analyzed as well.

\subsection{Pollutants Estimation}

COPERT 5.2.2 [22] was used to estimate pollutants emitted by both types of cars. COPERT is a program created as a European tool for calculating emissions from the road transport sector. It uses vehicle type, mileage, speed, and other data such as ambient temperature, and calculates emissions and energy consumption for a specific country or region. This program was developed to compile national emission inventories and has some limitations, especially in urban areas. Therefore, in this research, COPERT was used for comparing emissions on different routes but not for calculating an accurate pollutant value. Research input data are included in Table 3. The emissions equations are valid for Spain, even though they were customized for Caceres and the vehicles used in the experiment.

Table 3. COPERT input data.

\begin{tabular}{cccccccccc}
\hline \multirow{2}{*}{$\begin{array}{c}\text { Country } \\
\text { Month/Year }\end{array}$} & $\begin{array}{c}\text { Min } \\
\text { Temp }\end{array}$ & $\begin{array}{c}\text { Max } \\
\text { Temp }\end{array}$ & Humidity & Category & Fuel & Segment & $\begin{array}{c}\text { Euro } \\
\text { Standard }\end{array}$ & $\begin{array}{c}\text { Urban } \\
\text { Peak }\end{array}$ & $\begin{array}{c}\text { Urban } \\
\text { off } \\
\text { Peak }\end{array}$ \\
\hline $\begin{array}{c}\text { Spain } \\
\text { May/2017 }\end{array}$ & $13.4 \mathrm{C}$ & $26.8 \mathrm{C}$ & $47 \%$ & Passenger & $\begin{array}{c}\text { Petrol } \\
\text { Diesel }\end{array}$ & $\begin{array}{c}\text { Mini } \\
\text { Medium }\end{array}$ & Euro 5 & $25 \%$ & $75 \%$ \\
\hline
\end{tabular}

With this methodology, the study produced the following outputs: Fuel consumption, $\mathrm{CO}_{2}$, and regulated pollutants emissions (NOx, $\mathrm{CO}, \mathrm{VOC}, \mathrm{PM}$ ) for different types of vehicle, routes, and drivers.

\section{Results}

The analysis of the results was based on comparing both the data collected by the OBD-key device and the COPERT model outputs. Table 4 shows the number of trips and $\mathrm{km}$ driven for each alternative origin-destination route.

Table 4. Experimental statistics. Distance driven and the number of trips by route for each vehicle.

\begin{tabular}{lccccccc}
\hline & & & \multicolumn{5}{c}{ Number of Trips } \\
\cline { 4 - 8 } & Vehicle & $\begin{array}{c}\text { Total km } \\
\text { Driven }\end{array}$ & $\begin{array}{c}\text { R1 Local } \\
\text { Street }\end{array}$ & $\begin{array}{c}\text { R2 } \\
\text { Urban } \\
\text { Collector }\end{array}$ & $\begin{array}{c}\text { R3 } \\
\text { Perimeter }\end{array}$ & $\begin{array}{c}\text { R4 } \\
\text { Arterial } \\
\text { Road }\end{array}$ & Total \\
\hline \multirow{2}{*}{ Type } & Diesel, 1.61 & 1010 & 39 & 35 & 35 & 39 & 148 \\
& Petrol, 1.2 1 & 1091 & 40 & 34 & 34 & 34 & 142 \\
\hline \multirow{2}{*}{ Total } & - & 2101 & 79 & 69 & 69 & 73 & 290 \\
\hline
\end{tabular}

\subsection{Driver Performance}

Table 5 shows the driving variables recorded during the test, which were: Number of times below $5 \mathrm{~km} / \mathrm{h}$ (stops), average and maximum rpm, and different acceleration/deceleration. 
Table 5. Driver behavior parameters recorded and how they were dispersed.

\begin{tabular}{|c|c|c|c|c|c|c|c|c|}
\hline \multirow{2}{*}{$\begin{array}{l}\text { Parameters/Standard } \\
\text { Deviations }\end{array}$} & \multicolumn{2}{|c|}{ R1 Local Street } & \multicolumn{2}{|c|}{$\begin{array}{l}\text { R2 Urban } \\
\text { Collector }\end{array}$} & \multicolumn{2}{|c|}{ R3 Perimeter } & \multicolumn{2}{|c|}{ R4 Arterial Road } \\
\hline & 6.1 & 0.5 & 6.7 & 0.6 & 6.7 & 0.53 & 10.3 & 0.81 \\
\hline $\begin{array}{l}\text { Average number } \\
\text { of stops }\end{array}$ & 6.54 & 0.87 & 4.97 & 0.6 & 4.97 & 0.61 & 3.01 & 0.98 \\
\hline Average rpm & 1440 & 580 & 1493 & 502 & 1585 & 503 & 1812 & 648 \\
\hline Maximum rpm & 3506 & 665 & 3406 & 601 & 3536 & 614 & 3741 & 613 \\
\hline $\begin{array}{l}\text { Average positive } \\
\text { acceleration } \mathrm{m} / \mathrm{s}^{2}\end{array}$ & 0.35 & 0.11 & 0.36 & 0.1 & 0.44 & 0.11 & 0.54 & 0.13 \\
\hline $\begin{array}{l}\text { Maximum } \\
\text { positive } \\
\text { acceleration } \mathrm{m} / \mathrm{s}^{2}\end{array}$ & 2.31 & 0.82 & 2.07 & 0.8 & 2.25 & 1.05 & 2.66 & 0.96 \\
\hline $\begin{array}{l}\text { Average negative } \\
\text { acceleration } \mathrm{m} / \mathrm{s}^{2}\end{array}$ & -0.41 & 0.13 & -0.40 & 0.11 & -0.48 & 0.12 & -0.57 & 0.15 \\
\hline $\begin{array}{l}\text { Maximum } \\
\text { negative } \\
\text { acceleration } \mathrm{m} / \mathrm{s}^{2}\end{array}$ & -2.35 & 1.09 & -2.31 & 1.12 & -2.54 & 1.12 & -2.95 & 1.31 \\
\hline
\end{tabular}

The number of stops increased with traffic intensity. This was because urban roads have numerous traffic lights and pedestrian crossings while the arterial road (bypass) only has some level intersections with roundabouts. Moreover, average and maximum rpm decreased with the volume of traffic as well as average and maximum accelerations-decelerations. This can be explained by the fact that travelling speeds became higher with lower traffic intensity.

\subsection{Validated Fuel Consumption and Estimated $\mathrm{CO}_{2}$ Emissions}

Consumption information collected in the OBD-key was higher than the real data obtained with the petrol station tickets, thus, this item had to be adjusted and validated previously. Estimations of $\mathrm{CO}_{2}$ emissions were made from the technical data supplied by each vehicle. Figure 4 shows the results for both fuel types (petrol and diesel).

Figure 4 indicates a clear difference in consumption and $\mathrm{CO}_{2}$ emissions on urban routes (local street, urban collector, and perimeter) with respect to the bypass (arterial road), which on the arterial road was up to $34 \%$ higher for petrol and up to $54 \%$ higher for diesel vehicles. Additionally, consumption on urban routes was up to $27 \%$ lower in diesel engines than petrol ones. On the arterial road, consumption was similar in both engines. There appeared to be important differences between diesel and petrol vehicles in terms of $1 / 100 \mathrm{~km}$ consumption. Diesel results were more homogeneous than petrol ones. For diesel engines there were the same patterns in total consumption and unitary values: They increased with the level of infrastructure and itinerary length. As for petrol engines, there was a lower total consumption on urban roads than on the bypass, while in unitary terms these were all similar.

Since the aim of this research was to find the route on which there was the least consumption and emissions, the results indicated that on urban routes less fuel was consumed and less $\mathrm{CO}_{2}$ was emitted for both types of engine. Moreover, diesel engines showed more homogenous behavior among routes and traffic levels, while with petrol engine there were clearly different patterns, which depended on the urban and bypass itineraries.

Figure 5 shows fuel consumption by different driving turns, engines, and route types, including their variation with error bars. Although diesel vehicles were heavier and more powerful than petrol ones, they were more efficient on urban roads, while on the bypass they had a rather similar performance. 


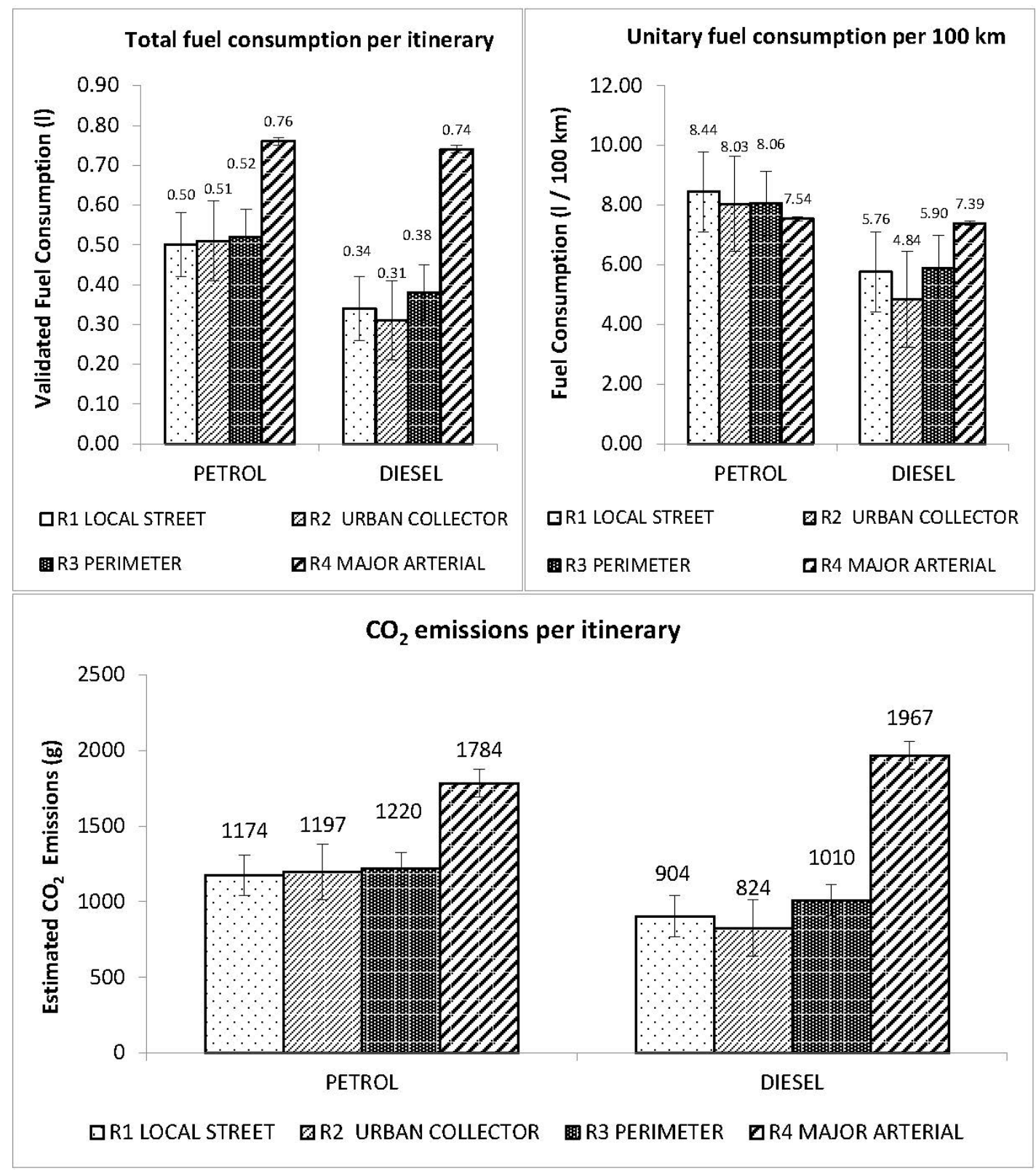

Figure 4. Fuel consumption and $\mathrm{CO}_{2}$ emissions for different routes and engines.

Figure 5 shows that for petrol cars the higher the congestion, the higher the consumption. These periods corresponded to lunch and the evening peak. Moreover, diesel engines displayed the highest consumption in the morning peak. However, fuel consumption differences were not very significant since congestion in Caceres did not entail long delays. 


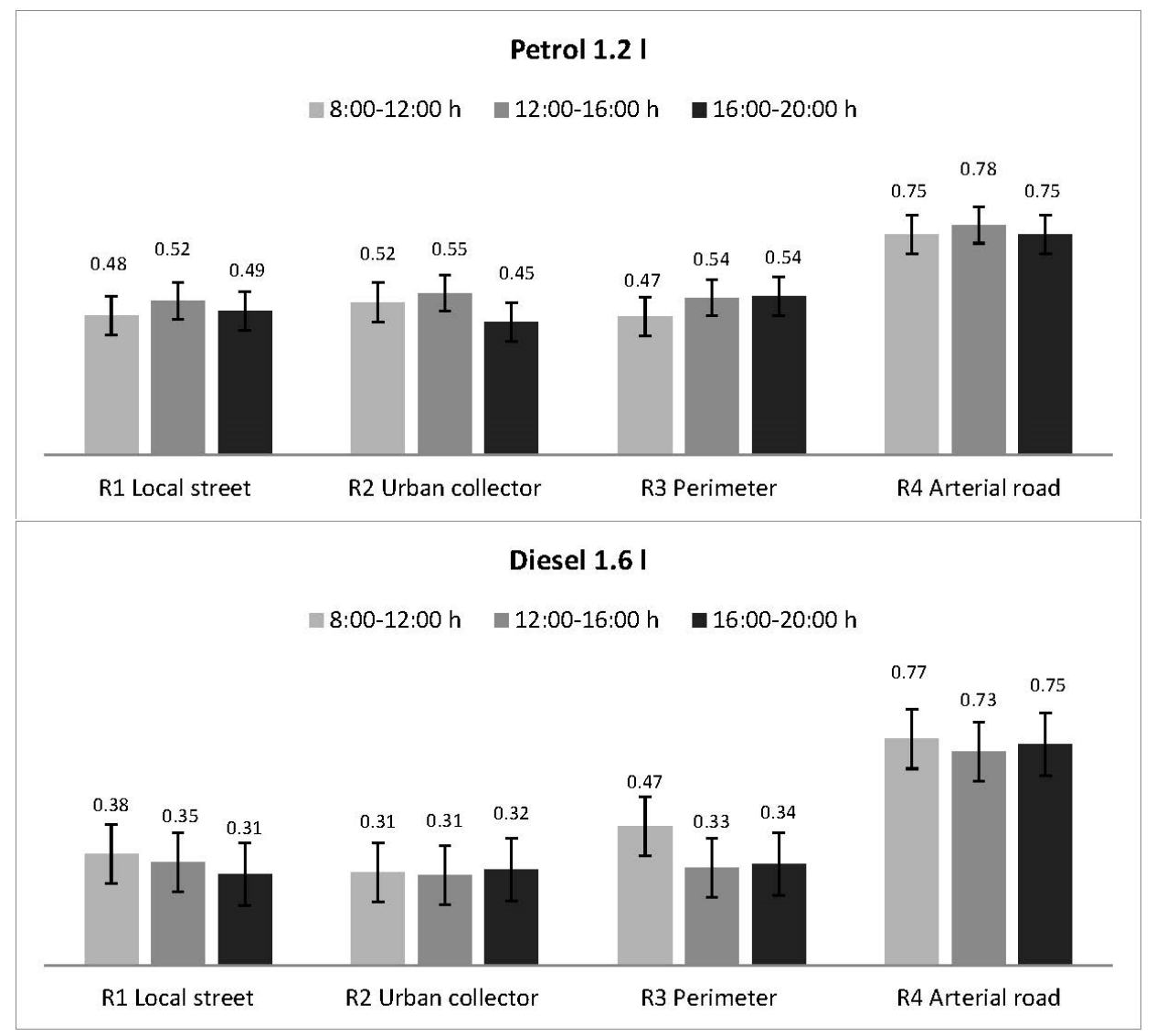

Figure 5. Fuel consumption (l) by driving turn, engine, and route type.

\subsection{Pollutants Estimation}

The pollutants NOx, CO, VOC, and PM were estimated by the type of route and engine by using the COPERT program (Figure 6). Since these were specific emissions values, which only depended on the characteristics of the vehicle, place, weather, and traffic, values have been provided without their error bars.

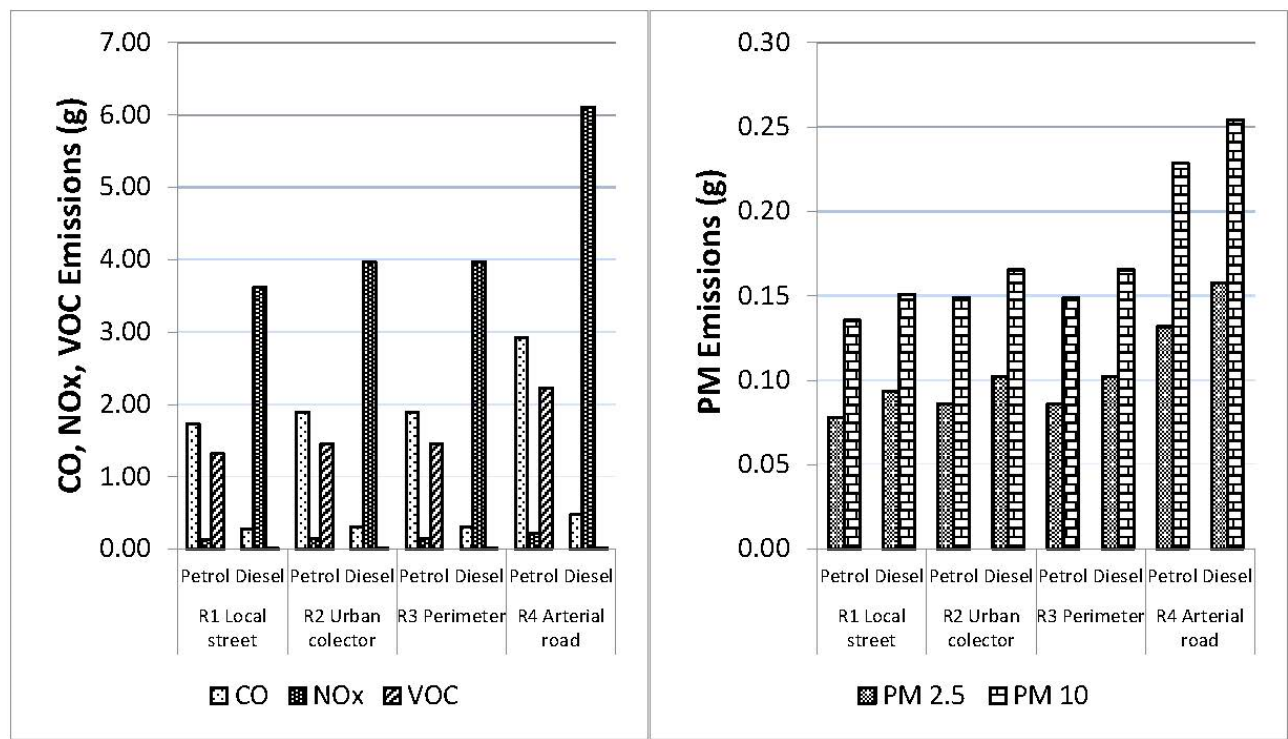

Figure 6. Pollutants emissions for different routes and engine types. 
Pollutant emissions increased as routes became longer, although they accounted for lower AADT. This meant that the most important factor for pollutant emissions was distance, as reported in the literature [33]. On urban routes, emissions were 35\% lower than those on the arterial road (bypass). Furthermore, diesel engines emitted much more NOx and slightly more PM than petrol ones, although less CO and VOC. Despite this, COPERT was not sensitive to congestion levels, the outputs of the experiment showed the impact of traffic in central and denser areas, where a large share of the population live, and most open air activities occurred.

\section{Discussion and Conclusions}

In this paper different factors that influenced the choice of eco-routes in a small city such as Caceres in Spain were studied. For this purpose, two cars (petrol and diesel) were monitored and 12 people drove for a week along with four different route types.

The results showed that on the local street route (the shortest) there were the fewest $\mathrm{CO}_{2}$ emissions and lowest pollution. This meant that consumption and emissions in cities like Caceres mostly depend on the distance travelled and not on other factors like time spent or the number of stops.

Slopes are rather similar and lower than $3 \%$ on average, therefore, we cannot measure their influence [34]. The R1-local street had the highest slope but it was also the one with the lowest consumption.

When choosing urban routes (local street, urban collector, and perimeter) as opposed to the bypass (arterial road) there was a decrease in total fuel consumption $/ \mathrm{CO}_{2}$ emissions of $34 \%$ in petrol engines and $54 \%$ in diesel ones. In the studies mentioned in the introduction [10-14], savings of only around $10 \%$ were reported. However, in other studies savings from $15 \%$ to $33 \%$ [15,35-37] were found, which are similar to those in this research. Consumption on the eco-route is always the lowest due to the difference in the length of the route. In Caceres, urban routes are $6.7 \mathrm{~km}$ long and the arterial road is $10.3 \mathrm{~km}$.

As for air pollution, pollutant emissions were reduced on urban routes by $35 \%$ on average. This result was higher than the savings reached in other green driving experiments, where in situations without important congestion levels, there were reductions of $13.8 \%$ and $20 \%[38,39]$. However, if there is very high congestion, air pollutants could increase a lot, as reported by Bandeira et al. [15] for CO (150\%) and NOx (46\%).

Drivers using the arterial road (bypass) reduced their travel time but were responsible for more $\mathrm{CO}_{2}$ emissions and air pollutants. However, by transferring traffic to external itineraries there was less congestion and emissions on the urban roads. Therefore, there needs to be a balance among the different itineraries in order to obtain the best overview: To reduce overall emissions and particularly pollution levels in denser areas, thereby reducing the exposure of pedestrian and cyclists to black carbon [40].

All in all, choosing urban routes in a small city reduces $\mathrm{CO}_{2}$ emissions and pollutants but increases emissions for the population that mostly live in the city center. Table 6 shows the advantages and disadvantages of choosing different itineraries.

Table 6. Effects of choosing different itineraries.

\begin{tabular}{lcc}
\hline \multicolumn{1}{c}{ Factor } & $\begin{array}{c}\text { Local Street, Urban Collector, } \\
\text { Perimeter (Urban Roads) }\end{array}$ & Arterial Road (Bypass) \\
\hline Fuel Consumption/ $\mathrm{CO}_{2}$ emissions & Positive & Negative \\
Pollutants emissions $(\mathrm{CO}, \mathrm{NOx}, \mathrm{PM})$ & Positive & Negative \\
Population affected by pollutants & Negative & Positive \\
Travel time & Negative & Positive \\
Congestion & Negative & Positive \\
\hline
\end{tabular}


These results obtained for a small city (Caceres) are similar to those obtained in a large city such as Madrid [38].

\section{Policy Recommendation and Future Research}

This research shows that on the urban routes tested, there is less consumption, $\mathrm{CO}_{2}$ emissions, and pollutants. The consumption and emission values for the urban routes are very similar although their characteristics change, e.g., one-lane local streets have similar consumption and emissions to urban collector with $2+2$ lane roads. Therefore, whenever less traffic congestion in small cities is needed, in light of this research, duplicating lanes (changing local streets to urban collectors) is preferable to building new city bypasses, which would mean higher construction costs and greater environmental damage.

A problem may arise if all drivers used the urban routes, which would lead to increased congestion. Future research should model these effects as done in big cities [38,41]. Moreover, how emissions are dispersed and how citizens inhale emitted pollutants would be highly important research. In addition, knowledge must be gained on how users accept eco-routes when that means a higher trip duration in order to reduce environmental harmful effects.

COPERT has been used to compare pollutants on different itineraries. However, COPERT shows problems to explain how speed varies with congestion, leading to under-estimations in pollutant emissions and fuel consumption in urban areas. The Passenger Car and Heavy Duty Emission Model (PHEM) for modelling on a small spatial scale [42] could be used in future research.

Results of this research indicate diesel vehicles behaved very similarly on urban and suburban routes. However, petrol cars had the same consumption values on the bypass but produced greater consumption on urban roads (total and unitary per kilometre). Therefore, traffic conditions had more influence on fuel consumption in petrol vehicles than diesel ones.

Promotional activities for selecting eco-routes in addition to other measures such as speed control, pedestrianization of the historic center, and limited-time parking are recommended for changing behavior in order to achieve sustainable city targets.

Author Contributions: J.F.C. was responsible for the test in Caceres and wrote the manuscript. M.G. coordinated the campaign and prepared the graphics and tables in the manuscript. Y.W. processed the data received by the OBD-key and A.M. was the main researcher, coordinated all the works, and reviewed the manuscript.

Funding: This research was funded by the Ministerio de Economía y Empresa (Government of Spain) in the National Programme Eco-Traffic "Medición y Modelización de Eco-Driving táctico y operacional". Ref TRA2016-76485-R (AEI/FEDER, UE).

Acknowledgments: Authors want to thank Caceres City Council for all the help received during the test.

Conflicts of Interest: The authors declare no conflict of interest.

\section{References}

1. European Commission. Urban Mobility. 2017. Available online: http://bit.ly/2kLbVDu (accessed on 16 July 2019).

2. Xia, H.; Boriboonsomsin, K.; Barth, M. Dynamic eco-driving for signalized arterial corridors and its indirect network-wide energy/emissions benefits. J. Intell. Transp. Syst. 2013, 17, 31-41. [CrossRef]

3. Ahn, K.; Rakha, H. The effects of route choice decisions on vehicle energy consumption and emissions. Transp. Res. Part D 2008, 13, 151-167. [CrossRef]

4. Wang, Y.; Boggio-Marzet, A. Evaluation of Eco-Driving Training for Fuel Efficiency and Emissions Reduction According to Road Type. Sustainability 2018, 10, 3891. [CrossRef]

5. Barkenbus, J.N. Eco-driving: An overlooked climate change initiative. Energy Policy 2010, 38, 762-769. [CrossRef]

6. Sivak, M.; Schoettle, B. Eco-driving: Strategic, tactical, and operational decisions of the driver that influence vehicle fuel economy. Transp. Policy 2012, 22, 96-99. [CrossRef] 
7. Strömberg, H.; Karlsson, I.M.; Rexfelt, O. Eco-driving: Drivers' understanding of the concept and implications for future interventions. Transport Policy 2015, 39, 48-54. [CrossRef]

8. Ecowill. The Golden Rules of Eco-Driving. 2013. Available online: http:/cieca.eu/sites/default/files/ documents/projects_and_studies/ECOWILL_FINAL_REPORT.pdf (accessed on 16 July 2019).

9. Boriboonsomsin, K.; Dean, J.; Barth, M. Examination of attributes and value of ecologically friendly route choices. Transp. Res. Rec. 2014, 2427, 13-25. [CrossRef]

10. Ericsson, E.; Larsson, H.; Brundell-Freij, K. Optimizing route choice for lowest fuel consumption-potential effects of a new driver support tool. Transp. Res. Part C 2006, 14, 369-383. [CrossRef]

11. Kono, T.; Fushiki, T.; Asada, K.; Nakano, K. Fuel Consumption Analysis and Prediction Model for "Eco" Route Search. In Proceedings of the 15th World Congress on Intelligent Transport Systems and ITS America's, New York, NY, USA, 16-20 November 2008; Available online: https://trid.trb.org/view/902235 (accessed on 15 June 2019).

12. Ahn, K.; Rakha, H. Network-wide impacts of eco-routing strategies: A large scale case study. Transp. Res. Part D 2013, 25, 119-130. [CrossRef]

13. Pandazis, J.C.; Winder, A. Study of Intelligent Transport Systems for reducing $\mathrm{CO}_{2}$ emissions for passenger cars. Eur. Road Transp. Telemat. Implement. Coord. Organ. 2015, 1, 49.

14. Zeng, W.; Miwa, T.; Morikawa, T. Prediction of vehicle $\mathrm{CO}_{2}$ emission and its application to eco-routing navigation. Transp. Res. Part C Emerg Technol. 2016, 68, 194-214. [CrossRef]

15. Bandeira, J.M.; Almeida, T.G.; Khattak, A.J.; Rouphail, N.M.; Coelho, M.C. Generating emissions information for route selection: Experimental monitoring and routes characterization. J. Intell. Transp. Syst. 2013, 17, 3-17. [CrossRef]

16. Mensing, F.; Bideaux, E.; Trigui, R.; Ribet, J.; Jeanneret, B. Eco-driving: An economic or ecologic driving style? Transp. Res. Part C 2013, 38, 110-121. [CrossRef]

17. Boriboonsomsin, K.; Barth, M.J.; Zhu, W.; Vu, A. Eco-routing navigation system based on multisource historical and real-time traffic information. IEEE Trans. Intell. Transp. Syst. 2012, 13, 1694-1704. [CrossRef]

18. Lin, Y.C.; Nguyen, H. Development of an eco-cruise control system based on digital topographical data. Inventions 2016, 1, 19. [CrossRef]

19. Guo, L.; Huang, S.; Sadek, A.W. An evaluation of environmental benefits of time-dependent green routing in the greater Buffalo-Niagara region. J. Intell. Transp. Syst. 2013, 17, 18-30. [CrossRef]

20. Transportation Research Board (TRB). Highway Capacity Manual 2010, 6th ed.; National Academy of Sciences: Washington, DC, USA, 2010; ISBN 978-0-309-16077-3.

21. OBDKey. KBM Systems Ltd.: London, UK, 2019. Available online: http://www.obdkey.com (accessed on 15 June 2019).

22. COPERT 5.2.2. Emisia, S.A.: Thessaloniki, Greece, 2019. Available online: https://www.emisia.com/utilities/ copert/download/ (accessed on 15 June 2019).

23. European Union. Regulation (EC) No 715/2007 of the European Parliament and of the Council of 20 June 2007 on Type Approval of Motor Vehicles with Respect to Emissions from Light Passenger and Commercial Vehicles (Euro 5 and Euro 6) and on Access to Vehicle Repair and Maintenance Information. 2007. Available online: https:/eur-lex.europa.eu/legal-content/en/ALL/?uri=CELEX\%3A32007R0715 (accessed on 15 June 2019).

24. UNESCO (United Nations, Educational, Scientific and Cultural Organization). Available online: http: //www.ciudadespatrimonio.org/ciudades/index.php?cd=3 (accessed on 15 June 2019).

25. Ayuntamiento de Cáceres. Plan de Infraestructuras para la Movilidad Urbana Sostenible. 2014. Available online: http://zetaestaticos.com/comun/upload/0/580/580017.pdf (accessed on 15 June 2019).

26. U.S. Department of Transportation. Highway Functional Classification: Concepts, Criteria and Procedure. 2013. Available online: https://www.fhwa.dot.gov/planning/processes/statewide/related/ highway_functional_classifications/fcauab.pdf (accessed on 15 June 2019).

27. Dirección General de Tráfico. Censo Conductores 2017. Available online: http://www.dgt.es/es/seguridadvial/estadisticas-e-indicadores/censo-conductores/tablas-estadisticas/2017/ (accessed on 15 June 2019).

28. Dirección General de Tráfico. Parque de Vehículos por Provincias. 2018. Available online: http://www.dgt.es/es/ seguridad-vial/estadisticas-e-indicadores/parque-vehiculos/tablas-estadisticas/ (accessed on 15 June 2019).

29. Instituto para la Diversificación y Ahorro de la Energía (IDAE). Consumo de Carburante y Emisiones de CO2 en Coches Nuevos. 2019. Available online: http://coches.idae.es/base-datos/marca-y-modelo (accessed on 15 June 2019). 
30. Ayuntamiento de Cáceres. Estudio de Tráfico y Movilidad. Revisión y Adaptación del Plan General Municipal de Cáceres. 2010. Available online: https://sig.caceres.es/PGM2010/TOMO_VI_EST_TRAFICO/ ESTUDIO_DE_TRAFICO_REFUNDIDO.pdf (accessed on 15 June 2019).

31. Coloma, J.F.; García, M.; Wang, Y. Eco-Driving Effects Depending on The Travelled Road. Correlation Between Fuel Consumption Parameters. Transp. Res. Procedia 2018, 33, 259-266. [CrossRef]

32. Ericsson, E. Independent driving pattern factors and their influence on fuel-use and exhaust emission factors. Transp. Res. Part D 2001, 6, 325-345. [CrossRef]

33. Andersen, O.; Jensen, C.S.; Torp, K.; Yang, B. Ecotour: Reducing the environmental footprint of vehicles using eco-routes. In Proceedings of the 2013 IEEE 14th International Conference on Mobile Data Management, Milan, Italy, 3-6 June 2013; Volume 1, pp. 338-340.

34. Kim, D.W.; Yoon, J.W.; Park, S.; Kim, K.; Lee, T. Fuel consumption parameters for realizing and verifying fuel consumption prospect algorithm of vehicle driving route information system. Int. J. Automot. Technol. 2013, 14, 955-964. [CrossRef]

35. Rakha, H.A.; Ahn, K.; Moran, K. Integration framework for modeling eco-routing strategies: Logic and preliminary results. Int. J. Trans. Sci. Technol. 2012, 1, 259-274. [CrossRef]

36. Zhou, M.; Jin, H.; Wang, W. A review of vehicle fuel consumption models to evaluate eco-driving and eco-routing. Transp. Res. Part D Transp. Environ. 2016, 49, 203-218. [CrossRef]

37. Dhaou, I.B. Fuel estimation model for ECO-driving and ECO-routing. In Proceedings of the 2011 IEEE Intelligent Vehicles Symposium (IV), Baden, Germany, 5-9 June 2011; pp. 37-42.

38. Perez-Prada, F.; Monzon, A.; Valdes, C. Managing traffic flows for cleaner cities: The role of green navigation systems. Energies 2017, 10, 791. [CrossRef]

39. Sun, J.; Liu, H.X. Stochastic eco-routing in a signalized traffic network. Transp. Res. Procedia 2015, 7, 110-128. [CrossRef]

40. Jereb, B.; Batkovič, T.; Herman, L.; Šipek, G.; Kovše, Š.; Gregorič, A.; Močnik, G. Exposure to Black Carbon during Bicycle Commuting-Alternative Route Selection. Atmosphere 2018, 9, 21. [CrossRef]

41. Garcia-Castro, A.; Monzon, A.; Valdes, C.; Romana, M. Modelling different penetration rates of eco-driving in urban areas. Impacts on traffic flow and emissions. Int. J. Sustain. Transp. 2017, 11, 282-294. [CrossRef]

42. Lejri, D.; Can, A.; Schiper, N.; Leclercq, L. Accounting for traffic speed dynamics when calculating COPERT and PHEM pollutant emissions at the urban scale. Transp. Res. Part D Transp. Environ. 2018, 63, 588-603. [CrossRef] 